\title{
Unpleasant Market Experience and Consumer Complaint Behavior
}

\author{
Nurzatul Hakimah bt Mahmud Mahayudin (Corresponding author) \\ Centre of Excellent for Sustainable Consumption Studies \\ Faculty of Human Ecology, Universiti Putra Malaysia \\ 43400 Serdang Selangor, Malaysia \\ Tel: 60-3-8946-7108Ｅ-mail: nurzatulhakimah@yahoo.com
}

\author{
Sharifah Azizah Haron \\ Centre of Excellent for Sustainable Consumption Studies \\ Faculty of Human Ecology, Universiti Putra Malaysia \\ 43400 Serdang Selangor, Malaysia
}

Tel: 60-3-8946-7108 E-mail: sh.azizah@putra.upm.edu.my

\author{
Benjamin Chan Yin Fah
}

Centre of Excellent for Sustainable Consumption Studies

Faculty of Human Ecology, Universiti Putra Malaysia

43400 Serdang Selangor, Malaysia

Tel: 60-3-8946-7097Ｅ-mail: sb2020@putra.upm.edu.my

\begin{abstract}
The $33 \%$ increase in number of complaints received by the National Consumer Complaint Centre (NCCC) in 2007 compared to previous year can mean two things: i) consumer are aware more of their rights or ii) the suppliers of goods and services perform worse in 2007. Unsatisfied consumer in either pre- or post consumption, complaint because of the unpleasant experiences in the consumption process or that the product perform below their expectation. The survey which utilized stratified random sampling with $61.7 \%$ of response rate was recorded. The objectives of the study are to analyze unpleasant experiences and complaint behavior among consumer. Findings indicated that respondents who are female, living in rural area and has higher level of assertiveness were more likely to encounter unpleasant experiences in marketplace. Further analysis indicated that, unpleasant experiences were mainly influenced by assertiveness rather than socio-demographics background or consumer knowledge.
\end{abstract}

Keywords: Consumer unpleasant experiences, Consumer complaint behavior

\section{Introduction}

Despite going programs by relevant authorities and wide coverage by the media on the plight of victims of financial fraud, such as pyramid scheme, access device fraud involving credit and debit card, electronic fund transfer fraud, telecommunication and computer fraud, many are still knowingly or unknowingly falling prey to the activities of fraudster. National Consumer Complaint Centre (NCCC) recorded a total of 24,873 complaints in 2007 (NCCC report, 2007) which resulted from unpleasant market experiences or dissatisfaction. Some consumer experiences dissatisfaction after purchasing and during consumption, these include various products and services provides by the unscrupulous business. To note almost $74 \%$ reported that they had at least one bad experience when buying products or service (AARP, 1999). The most common consumer complaints studied in this survey involve defective products or items or services that were not delivered when promised. The overall proportion of consumer in this study report that at least one bad experience had unchanged from 1993 to 1998. All these bad experiences will simply resulted dissatisfaction among consumer and complaining behavior. Consumer complaints were also as an outcome of dissatisfaction, which in many cases perceived a negative manner (Donoghue and Klerk, 2006). Hence, the objectives of the study are: 
1. To analyze unpleasant experiences and complaint behavior among consumer

2. To assess profiles of complaint behavior among consumer

3. To determine factors associated with unpleasant experiences among consumer

\section{Literature review}

\subsection{Unpleasant experiences, dissatisfaction and complaint behavior}

Experience is defined as the totality of a person's perception, thoughts and encounter by the consumers (Oliver, 1994). There are several types of consumption or used experiences which are i) experience with different products; ii) experience with similar products; and iii) experience with new product. These experiences can have either a direct or indirect influence on consumer satisfaction or dissatisfaction.

Previous studies on consumer dissatisfaction were more related to consumer disappointment. Bahr (1980) in his study stated that disappointment is one of measurement reason that being used as a substitute for dissatisfaction due to unfulfilled expectations. Which is product performance does not meet consumer expectation. Consumer unfulfilled expectation were mostly attributes to dissatisfaction or bad experiences or unpleasant experiences. While, in other study relate consumer dissatisfaction directly to product or performance expectation. Chen-Yu, Williams and Kincade (1999) in his study showed that performance expectation was a significant determinant of consumer dissatisfaction or satisfaction at the purchase stage. Hence, consumer dissatisfaction is seriously resulted from the discrepancy between expected and realized performance and dissatisfaction with an attribute which often arises from poor business practices (Adamson, 1991; Schouten and Van Raiij, 1990). Consumer satisfaction or dissatisfaction may relate to a particular feature or characteristic of a product or service, or it may relate a whole (European Commission, 2005). While, Bernhardt (1981) found that elderly consumers were reported to be less satisfied with their purchases compared to the younger group.

Consumer complaint behavior most probably were associated with consumer unsatisfied problem or unpleasant experiences. This is because bad experiences can lead to a negative feelings and consequently complaints. Hawes and Arndt (2007) found that a higher level of consumer complaints indicates dissatisfied consumer. As such, bad experiences would lead to a negative feeling and good experiences would lead to positive feelings, which, both of these experiences would resulted a complaints behavior either for a bad report or complimentary.

Various factors play an important role in complaint behavior such demographic factors such as age, gender and education level (Han et al., 1995). Age differences were found in the likelihood of having a dissatisfying experience, the demand for complaint actions, and the effects of determinants on complaint behavior (Lee and Ferrer, 1999). Based on previous findings, higher level of education was associated with the number of complaints as better-educated people know where and how to complaints (Day and Landon, 1977; Edgecombe et al., 1975; Han et al., 1995; Herrman et al., 1975; Mayer and Morganosky, 1987) compared to the lower education level. According to Haron and Paim (2008) lower income and education group have been identified as having most problem in unfair deals and deceptions in the market compared to the other consumer groups. While, personality and psychology factor as intervening variables caused delay or prevention from complaining due to the fear of confrontation and intimidation (Dacin and Davidow, 1997). In addition, consumers who are less assertive and conservative tend to have a lower self-confidence and afraid to take a risk towards complaining behavior (Keng and Liu, 1997). While, elderly are less likely to report a dissatisfying experience, though those who do express dissatisfaction are likely to take actions just like young consumers (Lee and Ferrer, 1999).

\section{Research Methods}

\subsection{The Data}

The data was obtained from a study on "Consumer Empowerment in a Globalized Market, funded by the Ministry of Higher Education, Malaysia under the Fundamental Grant Scheme. The survey covers the central region of Peninsular Malaysia namely the state of Selangor and the Federal Territories of Kuala Lumpur. Both places were chosen because Selangor is the most industrialized state and Kuala Lumpur is a metropolitan area in the Peninsula. As such, residents in both areas were more likely to be greatly exposed to various consumer related program conducted by various organizations.

The state of Selangor consisted of nine districts; i) Petaling, ii) Gombak, iii) Ulu Langat, iv) Sabak Bernam, v) Kuala Selangor, vi) Ulu Selangor, vii) Klang, viii) Kuala Langat and ix) Sepang. The district of Kuala Selangor, a non metropolitan city which consisted of nine subdivisions was randomly selected to represent the state of Selangor. Within the district of Kuala Selangor, three subdivisions namely Kuala Selangor, Jeram, and Bukit Rotan were randomly selected. Similarly, three zones within the Federal Territories of Kuala Lumpur, namely 
North, Central and South Kuala Lumpur were randomly selected. The list and map of housing areas were obtained from the Municipal office in each location.

The study collected data from residents of low cost housing in both areas. The rationale was that residents of low cost housing were more likely to be low income households with lower purchasing power and educational background. A total of 617 respondents were participated in this study. The data was collected using a set of questionnaires administered by trained enumerators with $61.7 \%$ of response rate.

\subsection{Variable definition and data analysis}

Consumer's unpleasant experiences in the market were assessed by asking consumers if they had experience such as following when purchasing good and/or services in the market: A newly purchased electrical or other good is not functioning (defective); A product warranty is not honored by the company; High charges for utility bills; A service you paid for was not delivered within the time it was promised; You were given a written estimate for a repair work; but the final bill turned out to be much higher than the estimate; You had your car repaired; but it still not functioning well after you drove home; Poor workmanship for house renovation; and Late delivery of a newly purchased house by developer. The respondents indicated either "yes" or "no" to each of the listed experiences.

While, consumer complaining behaviors were assessed by three types of action; i) those who had bad experiences but did not took action, ii) those who had bad experiences and took passive action, and iii) those who had bad experiences and took active action.

The Hierarchical Multiple Regression analysis was used to determine factors associated to unpleasant experiences. While, consumer complaints behaviors were analyzed using descriptive analyses and Chi square test.

\section{Findings}

A total of 617 respondents were participated in the study with $320(51.9 \%)$ respondents consisted of adult males. Majority of the respondents are 26 to 54 years old, whom are mostly married (85.3\%). The majority (84.3\%) of the respondents had secondary school education and lower, while $15.7 \%$ reported to have had higher than secondary education. The mean monthly household income for the sample was RM2,232.93 $(\underline{S D}=1668.61)$. The mean income for this sample was significantly lower than that of the National average of about RM3, 249 for Malaysia in general, and RM3,956 for urban areas in 2004 (Ninth Malaysia Plan, 2006). However, when assessed against the Poverty Line Income (PLI) of each respective areas (i.e. Kuala Lumpur and Selangor), only $11 \%$ of the respondents fell below the PLI, thus categorized as poor households. As such, majority of the respondents were consisted of low income group households.

Respondents were mostly experiences unpleasant situation after consumption activities, as such, newly purchased electrical or good which is defective $(28.5 \%)$. In fact, respondents in this study, also experiences a high charge for utility bills $(21.2 \%)$ and car repaired but still not functioning (16\%). Other than that, average respondents have a unpleasant experiences with services provided, such, higher final bills than estimate (8.4\%), no product warranty provided by the company $(8.3 \%)$, service paid was not delivered within the time it was promised $(8.1 \%)$, poor workmanship for house renovation $(7.0 \%)$ and late delivery of a newly purchased house developer.

The types of consumer complaint behavior was associated by sex, where more female than male prefer passive complaint approach. In contrast more male than female would prefer the active complaint approach. This can be explained by the differences personality hold by differences group. This contradict with the previous studies, that shows consumer complaining behavior were influenced by the age but more likely influenced by gender of the respondents.

Hierarchical Multiple Regression was use to identify the predictors of unpleasant experiences. The 1st Model found that female and those who lives in rural area are more likely to encounter unpleasant experiences. In terms of psychological factors (2nd Model) those who has higher level of assertiveness was more likely to encounter unpleasant experience. However, education and consumer knowledge are not the significance predictor.

\section{Conclusion and implication}

The study generally found that respondents who are female, living in rural area and has higher level of assertiveness were more likely to encounter unpleasant experiences in marketplace. Assertiveness was identified as main influence to unpleasant experiences rather than socio-demographics background or consumer knowledge. Most of the respondents still experienced unpleasant experiences despite having knowledge related to 
consumerism. Therefore, this calls for a more rigorous consumer education programs and intervention to mould the right personality and attitude among the consumers so that they become more prudent and reflective. Consumer education can be start since child to educate them to make a smart and good choice during purchasing, avoid impulse buying and educate them to reject unnecessary purchasing. At the same time, the business sector should give consumers value for money spent apart from conducting their activities in a fair and ethical manner. As this would encourage consumers as the backbone of any economy to spend more and wisely so it would be little production and few jobs so that country can recover faster from the spillover effects of a looming recession in the developed countries.

\section{References}

$2007^{\text {th }}$ Annual Report, National Consumer Complaints Centre (NCCC), Ministry of Domestic Trade and Consumer Affairs. Putrajaya.

Adamson, C.. (1991). Complaint handling: benefits and best practice. Consumer Policy Review, Vol. 1, No. 4, pp. 196-203.

American Association of Retired Persons (AARP). (1999). Consumer Behavior, Experiences and Attitudes: A Comparison by Age Groups. Washington, DC: AARP.

Bahr, W.J.. (1980). Consumer dissatisfaction or disappointment: A critical difference. Rockwell International. [Online] Available: http://lilt.ilstu.edu/staylor/csdcb/articles/1980/Bahr\%201980.pdf (January 21, 2010).

Berndhardt K.L.. (1981). Consumer problem and complaint actions of older consumer Americans: A National View. Journals of Retailing. Vol. 57, No. 3. pp 107-123.

Chen-Yu, H.J., Williams, G., \& Kincade, D.H.. (1999). Determinants of consumer satisfaction/dissatisfaction with the performance of apparel products. Family and Consumer Sciences Research Journal. Vol. 28 No. 2. pp 167-192.

Dacin, P.A. \& Davidow, M.. (1997). Understanding and influencing consumer complaint behavior: improving organizational complaint management, in Brucks, M. and MacInnis, D. (Eds), Advances in Consumer Research, Vol. 24, Association for Consumer Research, Provo, UT, pp. 450-6.

Day, R.L. \& Landon, E.L.. (1977). Toward a Theory of Consumer Complaint Behavior: Consumer and Industrial Buying Behavior. Elsevier, North-Holland Inc. pp. 425-37.

Donoghue, S., \& Klerk, H.M.D.. (2006). Dissatisfied consumers' complaint behavior concerning product failure of major electrical household appliances- a conceptual framework. Journal of Family Ecology and Consumer Sciences, Vol. 34, pp 42-55.

Edgecombe, F.H.C., Liefeld, J.P. \& Wolfe, L.. (1975). Demographic characteristics of Canadian consumer complainers. The Journal of Consumer Affairs, No. 9, pp. 73-80.

European Commission. (2005). Development of indicators on consumer satisfaction and pilot survey. [Online] Available: http://ec.europa.eu/consumers/topics/consumer_satisfaction_final_rep_en.pdf (June 26, 2009).

Han, S., Keng, K.A. \& Richmond, D.. (1995). Determinants of consumer complaint behavior: a study of Singapore consumers. Journal of International Consumer Marketing, Vol. 8, No. 2, pp. 59-76.

Haron, S.H., \& Paim, L.. (2008). How mature consumers handle unpleasant experience in the market? Malaysian Journal of Consumer and Family Economics. Vol. 11, pp 85 -94.

Hawes, D.K., \& Arndt, J.. (2007). Determining Consumer Satisfaction through Benefit Profiling. European Journal of Marketing 13, pp 284-298. Emerald Backfiles.

Herrman, R.O., Warland, R.H. \& Willits, J.. (1975). Dissatisfied consumer: who gets upset and who takes actions. Journal of Consumer Affair, Vol. 6, pp. 148-68.

Keng, K.A. \& Liu, S.. (1997). Personal Values and Complaint Behavior: The Case of Singapore Consumers. Journal of Retailing and Consumer Services. Vol. 4. No.2, pp 89-97.

Lee, J., \& Ferrer, H.S.. (1999). An Empirical Analysis of Elderly Consumers' Complaining Behavior. Family and Consumer Sciences Research Journal. 27:341.

Mayer, H. \& Morganosky, M.A.. (1987). Complaint behavior: analysis by demographics, lifestyle, and consumer values. Advances in Consumer Research, Vol. 14, No. 1, pp. 223-6.

Ninth Malaysia Plan. (2006). Economic Planning Unit, Prime Minister's Department. Putrajaya. 
Oliver H.M. Yau. (1994). Consumer Behavior in China: Customer Satisfaction and Cultural Values, T. J. Press (Padstow) Ltd, Padstow Cornwall.

Schouten, V. \& Van Raaij, W.. (1990). Consumer problems and satisfaction in a retail setting. Consumer Satisfaction / Dissatisfaction and Complaint Behavior, Vol. 3, pp. 56-60.

Table 1. Sample Characteristics

\begin{tabular}{|c|c|c|}
\hline \multirow[t]{2}{*}{ Variables } & \multicolumn{2}{|c|}{$\begin{array}{l}\text { All sample } \\
(\mathrm{N}=617)\end{array}$} \\
\hline & Frequency (n) & Percentage (\%) \\
\hline \multicolumn{3}{|c|}{ Age $($ Mean $=44$ years old, $S D=12.23)$} \\
\hline \multicolumn{3}{|l|}{$\leq 25$} \\
\hline $26-54$ & 36 & 5.8 \\
\hline \multirow[t]{2}{*}{55 and above } & 447 & 72.4 \\
\hline & 134 & 21.7 \\
\hline \multicolumn{3}{|l|}{ Sex } \\
\hline Male & 320 & 51.9 \\
\hline Female & 297 & 48.1 \\
\hline \multicolumn{3}{|l|}{ Marital status } \\
\hline Single & 91 & 14.7 \\
\hline Married & 526 & 85.3 \\
\hline \multicolumn{3}{|l|}{ Level of education } \\
\hline Secondary and lower & 520 & 84.3 \\
\hline $\begin{array}{l}\text { Upper Secondary or } \\
\text { higher }\end{array}$ & 97 & 15.7 \\
\hline \multicolumn{3}{|l|}{ Location } \\
\hline Urban & 342 & 55.4 \\
\hline Rural & 275 & 44.6 \\
\hline
\end{tabular}


Table 2. Distribution of respondents who had encounter bad experienced in the market

\begin{tabular}{|c|c|c|c|c|c|c|c|c|c|c|c|c|}
\hline \multirow{4}{*}{$\begin{array}{l}\text { Types of unpleasant } \\
\text { experiences }\end{array}$} & \multicolumn{4}{|c|}{ Bad Experiences } & \multirow{3}{*}{\multicolumn{2}{|c|}{$\begin{array}{c}\text { No } \\
\text { action }\end{array}$}} & \multicolumn{6}{|c|}{ Action } \\
\hline & \multirow{2}{*}{\multicolumn{2}{|c|}{ Yes }} & \multirow{2}{*}{\multicolumn{2}{|c|}{ No }} & & & \multirow{2}{*}{\multicolumn{2}{|c|}{ Passive }} & \multicolumn{4}{|c|}{ Active } \\
\hline & & & & & & & & & \multicolumn{2}{|c|}{$\begin{array}{l}\text { Deal with } \\
\text { company }\end{array}$} & \multicolumn{2}{|c|}{$\begin{array}{l}\text { Involved } \\
\text { third party }\end{array}$} \\
\hline & $\mathbf{n}$ & $\%$ & $\mathbf{n}$ & $\%$ & $\mathbf{n}$ & $\%$ & n & $\%$ & $\mathbf{n}$ & $\%$ & $\mathbf{n}$ & $\%$ \\
\hline $\begin{array}{l}\text { A newly purchased electrical } \\
\text { or other good is not } \\
\text { functioning }\end{array}$ & 176 & 28.5 & 441 & 71.5 & 35 & 5.7 & 94 & 15.2 & 47 & 7.6 & 4 & .6 \\
\hline $\begin{array}{l}\text { A product warranty is not } \\
\text { honored by the company }\end{array}$ & 51 & 8.3 & 566 & 91.7 & 24 & 3.9 & 37 & 6.0 & 8 & 1.3 & 1 & .2 \\
\hline High charges for utility bills & 131 & 21.2 & 486 & 78.8 & 72 & $\begin{array}{r}11 . \\
7\end{array}$ & 52 & 8.4 & 3 & .5 & 6 & 1.0 \\
\hline $\begin{array}{l}\text { A service you paid for was } \\
\text { not delivered within the time } \\
\text { it was promised }\end{array}$ & 50 & 8.1 & 567 & 91.9 & 25 & 4.1 & 34 & 5.5 & 7 & 1.1 & 1 & .2 \\
\hline $\begin{array}{l}\text { You were given a written } \\
\text { estimate for a repair work, but } \\
\text { the final bill turned out to be } \\
\text { much higher than the estimate }\end{array}$ & 52 & 8.4 & 565 & 91.6 & 22 & 3.6 & 23 & 3.7 & 8 & 1.3 & 7 & 1.1 \\
\hline $\begin{array}{l}\text { You had our car repaired, but } \\
\text { it still not functioning well } \\
\text { after you drove home }\end{array}$ & 99 & 16.0 & 518 & 84.0 & 21 & 3.4 & 46 & 7.5 & 36 & 5.8 & - & - \\
\hline $\begin{array}{l}\text { Poor workmanship for house } \\
\text { renovation }\end{array}$ & 43 & 7.0 & 574 & 93.0 & 20 & 3.2 & 19 & 3.1 & 8 & 1.3 & 4 & .6 \\
\hline $\begin{array}{l}\text { Late delivery of newly } \\
\text { purchased house by developer }\end{array}$ & 28 & 4.5 & 589 & 95.5 & 18 & 2.9 & 12 & 1.9 & 2 & .3 & 4 & .6 \\
\hline
\end{tabular}


Table 3. Distribution of respondents who had encountered bad experiences and took action

\begin{tabular}{|c|c|c|c|c|c|c|c|c|c|}
\hline \multirow{3}{*}{ Variable } & \multicolumn{6}{|c|}{ Consumer complaint } & \multirow{2}{*}{\multicolumn{2}{|c|}{ Total }} & \multirow{3}{*}{$\begin{array}{l}\text { Pearson } \\
\text { Chi Square }\end{array}$} \\
\hline & \multicolumn{2}{|c|}{ Did nothing } & \multicolumn{2}{|c|}{$\begin{array}{l}\text { Passive } \\
\text { complaint }\end{array}$} & \multicolumn{2}{|c|}{$\begin{array}{c}\text { Active } \\
\text { complaint }\end{array}$} & & & \\
\hline & $\mathrm{n}$ & $\%$ & $\mathrm{~N}$ & $\%$ & $\mathrm{n}$ & $\%$ & $\mathrm{n}$ & $\%$ & \\
\hline Age & & & & & & & & & \\
\hline Below and 25 & 5 & 1.7 & 6 & 2.0 & 6 & 2.0 & 17 & 5.7 & n.s \\
\hline $26-54$ & 33 & 11.0 & 109 & 36.3 & 88 & 29.3 & 230 & 76.7 & \\
\hline 55 and above & 9 & 3.0 & 21 & 7.0 & 23 & 7.7 & 53 & 17.7 & \\
\hline Sex* & & & & & & & & & \\
\hline Male & 28 & 9.3 & 59 & 19.7 & 71 & 23.7 & 158 & 52.7 & $\chi^{2}=8.619$ \\
\hline Female & 19 & 6.3 & 77 & 25.7 & 46 & 15.3 & 142 & 47.3 & $\mathrm{p}=.013$ \\
\hline Household Income & & & & & & & & & \\
\hline Below and RM6900.00 & 46 & 15.3 & 133 & 44.3 & 113 & 37.7 & 292 & 97.3 & n.s \\
\hline RM6900.00 and above & 1 & .3 & 3 & 1.0 & 4 & 1.3 & 8 & 2.7 & \\
\hline Marital status & & & & & & & & & \\
\hline Single & 9 & 3.0 & 12 & 4.0 & 19 & 6.3 & 40 & 13.3 & n.s \\
\hline Married & 38 & 12.7 & 124 & 41.3 & 98 & 32.7 & 260 & 86.7 & \\
\hline Level of education & & & & & & & & & \\
\hline Secondary and below & 39 & 13.0 & 111 & 37.0 & 95 & 31.7 & 245 & 81.7 & n.s \\
\hline Upper secondary or higher & 8 & 2.7 & 25 & 8.3 & 22 & 7.3 & 55 & 18.3 & \\
\hline Location & & & & & & & & & \\
\hline Urban & 25 & 8.3 & 79 & 26.3 & 64 & 21.3 & 168 & 56.0 & n.s \\
\hline Rural & 22 & 7.3 & 57 & 19.0 & 53 & 17.7 & 132 & 44.0 & \\
\hline
\end{tabular}

$* p \leq 0.05$

Table 4. Summary of Hierarchical Regression Analysis to determine factors associated with unpleasant experiences

\begin{tabular}{|c|c|c|c|c|}
\hline \multirow[t]{2}{*}{ Model } & \multicolumn{2}{|c|}{$\begin{array}{l}\text { Unstandardized } \\
\text { Coefficients }\end{array}$} & \multirow{2}{*}{$\begin{array}{c}\begin{array}{c}\text { Standardize } \\
\text { d } \\
\text { Coefficients }\end{array} \\
\text { Beta }\end{array}$} & \multirow[t]{2}{*}{ Sig. } \\
\hline & B & Std. Error & & \\
\hline \multicolumn{5}{|c|}{ Model 1: Socio economic status $\left(\mathrm{F} 617=3.653, \mathrm{df}=5, \mathrm{p} \leq 0.01, \Delta \mathrm{R}^{2}=0.021\right)$} \\
\hline (Constant) & 15.073 & .488 & & .000 \\
\hline Age & .007 & .115 & .003 & .949 \\
\hline Sex & .247 & .111 & .090 & .026 \\
\hline Household Income & -.374 & .386 & -.039 & .332 \\
\hline Level of education & -.078 & .158 & -.021 & .619 \\
\hline Location* & .369 & .111 & .133 & .001 \\
\hline \multicolumn{5}{|c|}{ Model 2: Psychological factors $\left(\mathrm{F} 617=5.423, \mathrm{df}=6, \mathrm{p} \leq 0.01, \Delta \mathrm{R}^{2}=0.041\right)$} \\
\hline (Constant) & 16.886 & .685 & & .000 \\
\hline Assertiveness* & .126 & .034 & .148 & .000 \\
\hline \multicolumn{5}{|c|}{ Model 3: Consumer Knowledge (F $\left.617=4.179, \mathrm{df}=8, \mathrm{p} \leq 0.01, \Delta \mathrm{R}^{2}=0.040\right)$} \\
\hline (Constant) & 16.890 & .705 & & .000 \\
\hline Consumer rights & .025 & .117 & .009 & .832 \\
\hline $\begin{array}{c}\text { Self assessed consumer } \\
\text { knowledge }\end{array}$ & -.111 & .115 & -.039 & .337 \\
\hline
\end{tabular}

